\section{Mice with a human touch}

Years of tinkering with the mouse immune system genes has

finally produced a winner, with the approval of the first fully human

monoclonal antibody made in a mouse. A real breakthrough or an

incremental improvement? Christopher Thomas Scott investigates.

In September, 2006, the monoclonal antibody Vectibix (panitumumab), offered by Thousand Oaks, California-based Amgen, gained US Food and Drug Administration (FDA) approval for epidermal growth factor receptor (EGFR)expressing colorectal cancers, the first totally human antibody made in a transgenic mouse. The 20-year quest to humanize mouse antibodies to avoid host immune responses had finally reached fruition.

But the path to success has had its share of drama, with a patent dispute between two companies with competing humanizing mouse platforms that left one nearly penniless. And while all this was going on, a rash of less than totally human antibodies has entered the clinic, largely without incident, though one disastrous clinical trial could have brought the sector to its knees. And if that weren't enough, Vectibix's target is in the cross hairs of several other marketed antibodies as well as some drugs in clinical trials. Whether Vectibix will be met with the same excitement in the clinic as it has in the boardroom remains to be seen. But at least for the moment, the spotlight is on the rodent that made it, the Xenomouse (Fig. 1).

\section{Monoclonal saga}

Two years after Niels Jerne, César Milstein and George Köhler received the 1984 Nobel prize in physiology or medicine for developing the technology to produce monoclonal antibodies (mAbs), the FDA approved the first mouse $\mathrm{mAb}$ product, Orthoclone OKT3 (muromab), made by Johnson \& Johnson of New Brunswick, New Jersey. The drug targeted human T-cell CD3 antigen and was prescribed to prevent rejection of transplanted kidneys ${ }^{1}$. Its shortcomings presaged the major problem with this class of drug: after the first treatment, the patient makes antibodies against the constant $(\mathrm{C})$ regions of the mouse antibody, decreasing its effectiveness and increasing the likelihood of complications.

To get around the immunogenetic properties of mAbs, researchers began a quest using genetic engineering to make hybrid products combining mouse variable $(\mathrm{V})$ regions with human $\mathrm{C}$ regions. As a result, chimeric and humanized mAbs - those with murine variable regions or murine complementarity-determining

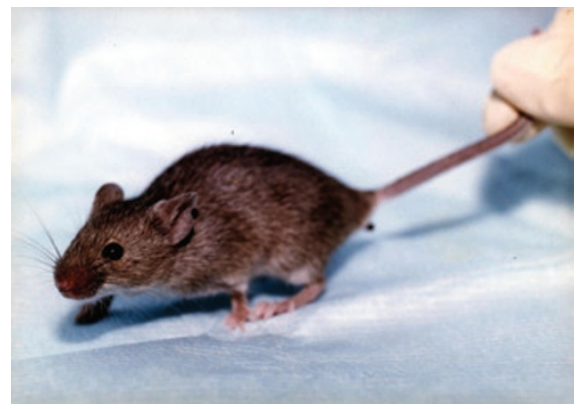

Figure 1 Engineering tour de force-the Xenomouse. Inactivating the mouse's own antibody genes while supplying human counterparts has led to the first fully human mAb drug made in a transgenic mouse. Source: Aya Jakobovitz.

regions on a human scaffold- have gained fast acceptance as an effective class of therapeutics. Current generation drugs include humanized compounds such as the S. San Francisco-based Genentech's breast cancer drug Herceptin (trastuzumab). Chimeric technologies include the anti-tumor necrosis factor (TNF) antibody Remicade (infliximab) produced by Centocor, a subsidiary of Johnson and Johnson, located in Horsham, Pennsylvania and prescribed for Crohn's desease and arthritis. The first fully human $\mathrm{mAb}$, the phage display-generated Humira (adalimumab) from Abbott of Abbott Park, Illinois, and Cambridge Antibody Technology, a subsidiary of AstraZeneca of London, is an anti-TNF- $\alpha$ drug targeting Crohn's disease, rheumatoid arthritis and ankylosing spondylitis.

Though cancer and autoimmune diseases are prime foci for many $\mathrm{mAb}$ drugs, new targets have emerged, such as AIDS and severe acute respiratory syndrome (SARS). Human respiratory syncytial virus (RSV) infections, which cause significant mortality in infants, are successfully treated with a humanized anti-RSV antibody, Synagis (palivizumab) made by Medimmune of Gaithersburg, Maryland. Synagis is chimeric: six variable regions from the mouse $\mathrm{mAb}$ are inserted into a human IgG framework. A third targets RANKL, a TNF-family member stimulating the activation of osteoclasts. The drug, Amgen's denosomab, was made using the company's fully-human transgenic mouse and is in phase 3 clinical testing for bone resorption in postmenopausal women.

\section{Rough waters for a superagonist}

But not everything was smooth sailing for new candidates and the companies that made them. The most widely publicized casualty is Germany's TeGenero. The company's lead drug, TGN1412, was a chimeric drug made by fusing mouse and human cells. Six male volunteers suffered severe immune responses during the company's disastrous phase 1 trial, conducted in the spring of 2006 at London's Northwick Park Hospital ${ }^{2}$.

The clinical trial spelled the end for TeGenero, which went bankrupt that summer. Peter Parham, a Stanford University immunologist who studies the biology and evolution of major histocompatibility complex class I molecules, recalled hearing the TeGenero news. "I thought monoclonals would die on the vine," he recalls. "But after looking at recent results, it looks like they will do all right after all." Parham singles out Rituxan (rituximab) offered by Genentech and Biogen Idec, of Cambridge, Massachusetts, a chimeric $\mathrm{mAb}$ that targets $\mathrm{CD} 20^{+} \mathrm{B}$ cells, which has been given to 600,000 lymphoma and arthritis patients as a case in point, noting the drug's safety record and gradual expansion for use in cancer and autoimmune disease.

Despite the trouble with TGN1412, the market remains piping hot for approved products. Rituxan, Synagis and Centocor's ReoPro (abiciximab) each have annual revenues south of $\$ 3$ billion. Since 1997, 18 mAb-based drugs have found the market, and 150 more are under development ${ }^{3}$. The mAb development timelines, from fully mouse in 1975 to fully human in 2006, have averaged about 12 years - altogether strong performances for a field so young.

\section{The race for the fully humanized mouse}

'Humanized' mice with functional immunoglobulin loci of their own express both mouse and human antibodies and yield some, but not all, of the diversity present in a natural system. The primary limitation of most approved $\mathrm{mAb}$ drugs is the immune response in patients who take them-usually against the remaining mouse components of the antibody. Making transgenic mice that produced fully human antibodies, while making none of their own, became the next technical hurdle.

Like many things in biotech, it was a race to get there. In 1994, two San Francisco Bay Area companies, GenPharm and Cell Genesys, reported they had engineered mice to make fully human antibodies, now commonly called 'HumAb' mice. The GenPharm method, developed by its chief scientist, Nils Lonberg, now 
senior vice president and scientific director at Medarex in Princeton, New Jersey, used homologous recombination to disrupt the mouse immunoglobulin genes and pronuclear injection to deliver components of light and heavy human transgenes, including constant and variable (V), diversity (D) and joining (J) regions. The Cell Genesys group also disabled the mouse machinery, but used protoplasts to deliver large fragments of the relevant chromosomes with a yeast artificial chromosome (YAC) system. In both cases, the constructs went through VDJ joining, a natural process producing antibody diversity. In addition, B cells with a low affinity for the antigen embark on T-cell affinity maturation, which relies on somatic mutations to make antibodies that bind tightly to the target.
Cell Genesys spun out Abgenix in 1996, with the mouse as its mascot. The company searched for a partner to develop its anticancer drug, now known as Vectibix, which targets the EGFR. It found one in Seattle-based Immunex. Amgen acquired Immunex in 2002, and with it the Abgenix codevelopment deal. The biotech giant liked what it saw, and completed the circle in 2005, buying Abgenix for $\$ 2.2$ billion $^{4}$. It managed the last stages of clinical trials and Vectibix was approved for colorectal cancer in 2006 , the first approved fully human mAb product made from any human Ig mouse technology, called the XenoMouse (see p. 1127, this issue). Aya Jakobovits, originally at Cell Genesys and later at Abgenix, shepherded the XenoMouse through its entire development. The strategy for the new technology, says Jakobovits, who is now senior vice president and chief scientific officer at privately owned Agensys in Santa Monica, California, "was to deliver the entire immunoglobulin locus into the mouse germ line. We successfully transferred megabyte-sized pieces of human immunoglobulin into a murine humoral immune system." Amgen now offers six strains of mice making human IgG1, 2 and 4 heavy chains in combination with the human kappa and lambda light chain sequences.

In a parallel trajectory, GenPharm pushed ahead, but not without causing a ruckus. Cell Genesys sued them in 1994 for theft of trade secrets. GenPharm returned the favor with an infringement countersuit, and the fight was on. For venture-backed GenPharm, it became a war of attrition. Cell Genesys, a public company backed by government-owned Japan Tobacco,

\section{Box 1 A crowded space}

Vectibix is far from the only drug targeting EGFR. One chimeric antibody, Erbitux (cetuximab) is approved and several humanized mAbs are under development. Among the approved EGFR-targeting drugs there are no head-to-head comparisons. Like Vectibix, Erbitux, marketed by New York's ImClone and Princeton, New Jersey's Bristol-Myers Squibb, targets the extracellular domain EGFR for colorectal cancer. No clinical trial has fully tested the differences between a chimeric and fully human product. One potentially confounding issue for future studies is that whereas both Vectibix and Erbitux are IgG antibodies, they vary in the constant domain. Erbitux is an IgG1 subclass, Vectibix an IgG2.

But cross-trial comparisons for monotherapies exist. Vectibix takes longer to clear and, as a result, is dosed less frequently and at lower levels. Grade 3 or 4 infusion reactions are lower with Vectibix, ranging from $0 \%$ to $1 \%$, about half the number reported for Erbitux. Both produce skin rashes, which are unrelated to the mechanism of action but an activity bellwether for all EGFR products. The clinical effects appear to be similar. Individuals with colorectal cancer responding to the drug and those showing stable disease in a phase 3 Vectibix trial ( $10 \%$ and $28 \%$, respectively) compare closely to those in a phase 2 Erbitux trial (10\% and 32\%, respectively) ${ }^{8,9}$ (Table 1 ).

Copenhagen-based Genmab's IgG1 EGFR product for head and neck cancer (HuMax-EGFr, zalutumumab) behaves very much like Vectibix in preclinical studies. In June, the company announced that HuMax - made using a Medarex mouse-inhibited the growth of in vitro grown lung cancer tumor cells expressing both mutated or normal EGFRs, and showed cell-killing activity called antibody-dependent, cell-mediated cytotoxicity. Once
Genmab's pivotal phase 3 results for head and neck cancer are in, a clinical comparison between the two molecules could uncover information about the efficacy and safety of the IgG class of drugs.

On other fronts, a humanized mAb targeting EGFR, TheraCIM (nimotuzumAb), has been approved in Argentina, China, Columbia, India and Cuba for inoperable head and neck cancer. In August, the Ontario, Canada drugmaker YM Biosciences announced it was targeting colorectal cancer, using the drug in combination with the chemotherapeutic agent Camptosar (irinotecan).

Another high-affinity EGFR product is EMD (formerly EMD 72000; matuzumab from Serono of Rockland, Massachusetts). In recent studies, the humanized $\mathrm{mAb}$ with chemotherapy was active against pancreatic cancer, adenocarcinomas and other solid tumors ${ }^{10}$. Although Vectibix/chemotherapy combinations are still an open question, the compound might be used as a second or third-line treatment. The drug could be useful for those who can't tolerate Erbitux or who need repeated, long-term dosing regimens.
Table 1 Vectibix meets Erbituxa

\begin{tabular}{|c|c|c|}
\hline Parameter & Erbitux & Vectibix \\
\hline Components & Chimeric human and mouse & Human only \\
\hline FDA-approved indication & $\begin{array}{l}\text { EGFR-expressing metastatic } \\
\text { colorectal cancer }\end{array}$ & $\begin{array}{l}\text { EGFR-expressing metastatic } \\
\text { colorectal cancer }\end{array}$ \\
\hline Patient profile & $\begin{array}{l}\text { Patients intolerant to Camptosar } \\
\text { (irinotecan) (chemotherapy) }\end{array}$ & $\begin{array}{l}\text { Patients with disease progression or after } \\
\text { chemotherapy }\end{array}$ \\
\hline Administration & $\begin{array}{l}\text { Loading dose }\left(400 \mathrm{mg} / \mathrm{m}^{2} \text { i.v. }\right) \\
\text { Weekly }\left(250 \mathrm{mg} / \mathrm{m}^{2} \text { i.v. }\right)\end{array}$ & $6 \mathrm{mg} / \mathrm{kg}$ every 14 days \\
\hline $\begin{array}{l}\text { Common toxicities } \\
\text { Dermatologic } \\
\text { Infusion reaction } \\
\text { Diarrhea } \\
\text { Pulmonary }\end{array}$ & $\begin{array}{l}8 \% \text { (grade } 3 \text { ) } \\
2 \% \text { (grade } 3-4 \text { ) } \\
2 \% \text { (grade } 3-4 \text { ) } \\
\text { interstitial lung disease }<0.5 \%\end{array}$ & $\begin{array}{l}14 \% \text { (grade } 3-4 \text { ) } \\
1 \% \text { (grade } 3-4 \text { ) } \\
2 \% \text { (grade } 3-4 \text { ) } \\
\text { pulmonary fibrosis < } 1 \%\end{array}$ \\
\hline Clinical effects & $10 \%$ response; $32 \%$ stable disease & $10 \%$ response; $28 \%$ stable disease \\
\hline Immunoglobulin subtype & $\lg G 1$ & $\lg G 2$ \\
\hline Cost/month ${ }^{\mathrm{b}}$ & $\$ 12,000^{c}$ & $\$ 9,599.94^{d}$ \\
\hline
\end{tabular}

a Data taken from ref 8 and 9 and literature search. ${ }^{b}$ Based on average wholesale price for maintenance therapy only. ${ }^{\mathrm{C}}$ Based on body surface of $1.7 . \mathrm{m}^{2}$ rounded up to the nearest vial size of $100 \mathrm{mg}$. ${ }^{\mathrm{d}}$ Based on $70-\mathrm{kg}$ patient rounded up to the nearest vial size of $100 \mathrm{mg}$. 
kept the legal fires burning. GenPharm, spending money on its defense, had to pull its initial public offering and slashed its staff from over 100 to seven. Then, as suddenly as it began, it was over. In March of 1997, Cell Genesys dropped the suit and paid GenPharm a $\$ 40$ million crosslicense settlement. Lonberg recalls his relief after glimpsing the abyss: "We were down to bartering for lab space. Our lawyers were on a no-cash contingency." Six months later, salvation arrived. Medarex bought the company for a \$62 million stock swap. (Cell Genesys executives declined to be interviewed for this article.)

Just as the Abgenix/Amgen merger was good for the XenoMouse, the Medarex buyout rescued GenPharm's rodent. Through a partnership with the pharmaceutical division of Kirin Brewery, Medarex has made a second mouse with genes that encode all the immunoglobulin isotypes ( $G, A, D, M$ and $E$ ). These are crossbred to the GenPharm strains. "We use several different mouse strains with different fractions of the repertoire-we immunize all of them, so we're agnostic about the tool," Lonberg explains. Now Medarex has $34 \mathrm{mAbs}$ in clinical development, seven in phase 3 , and the company has a financial stake in all of them, either through potential sales, royalty payments or equity interest in the partner company. Amgen-playing all the bases-has licensed four candidates for undisclosed diseases.

Those familiar with mice say they offer multiple advantages. Most importantly, the antibodies consist of fully human protein sequences. The second advantage centers on the evolution-tuned mechanics of the mouse humoral system. Diverse numbers can be made simultaneously, and repeated immunization generates high affinities without further engineering. Bellur S. Prabhakar, professor and head of the Department of Microbiology and Immunology at the University of Illinois at Chicago, has used the XenoMouse to make neutralizing human mAbs against the SARS virus. He adds more plusses: "The immunoglobulin gene can be cloned and used to generate recombinant cell lines. The system lets you pick an antibody by its mechanism of action, such as whether it's an agonist or antagonist. You can ask functional questions, too, such as whether they neutralize a toxin."

Or in the case of Amgen's big approval for Vectibix, neutralize cancer (Box 1, Table 1).

\section{The $\$ 120,000,000$ mouse}

Are fully humanized mice the apex of monoclonal technologies? George Yancopoulos, chief science officer at Regeneron Pharmaceuticals of Tarrytown, New York, first introduced human immunoglobulin elements into mouse B cells in 1985. He likes transgenic mAb mice-his company had a collaboration using the Medarex platform — and calls them premier technologies. But transgenic mice are, after all, chimeras, and any laboratory working with the critters knows they can be fussy and don't breed well. For the new mouse technologies, add a rickety immune system to the list. "You need more animals, more intensive immunization approaches and robust screening methods to get the numbers to sample," he says. "There has to be a better way."

The better way is what Yancopoulos calls the "largest genomic engineering project ever contemplated, let alone actually completed"-the Velocilmmune mouse. Instead of disabling the mouse immune system, his group left the transcriptional control elements and constant regions in place. They precisely replaced every mouse variable region (hundreds of them, 6 megabases total) with their human heavy and light chain counterparts. The result is, according to Yancopoulos, a transgenic mouse that is indistinguishable from a normal mouse- - they even breed, well, like mice. Two megadeals validate his enthusiasm. AstraZeneca, despite having access to the XenoMouse and owning CAT (the phage display company behind Humira), forked out over \$120 million for a few breeding pairs of VelocImmune mice. Astellas Pharmaceuticals located in Tokyo did the same. Both deals are nonexclusive, with Regeneron capturing downstream royalties.

\section{Fast-fading phages?}

Phage display clones human antibody genes and screens them for the best candidates using suspect antigenic proteins and peptides. Garry Nolan, the Stanford phage display expert who pioneered technologies that formed the cornerstone of S. San Francisco-based Rigel Pharmaceuticals puts his finger on the limitations of phage display technology. "Mixing and matching human heavy and light chains will give you $10^{9}$ different mAbs, he says. "The problem is the product isn't antigen matured, and as a result it can be low affinity." To some, the distinction is academic, pitting quantity against quality. And Yancopoulos reminds us of the natural beauty of affinity maturation: "Affinity maturation in a phage system is a manual step-you have to go back and reverse engineer the antibody for better properties. The normal mouse already does this-it's the better way to go."

That said, it's hard to argue with Humira's success. And supporters of in vitro engineering approaches maintain, not surprisingly, that the black box of the mouse system can't offer the advantages of phage display's speed, control and size. Morphosys of Planegg, Germany, has a fully human combinatorial platform that swaps complimentarity-determining regions, a bulging preclinical pipeline, but no candidate past phase
1. Cambridge Antibody Technology's roster is clotted with nearly a dozen candidates in early phase trials. Outside of its flagship Humira, only one candidate has progressed beyond phase 2 , a compound for systemic lupus.

\section{The future gets smaller}

Ask a monoclonal expert what lies ahead, and they'll likely say, "check with Pim." They refer to Willem 'Pim' Stemmer, a rapid-fire serial entrepreneur with 80 patents to his credit and a fondness for leeches, venomous snakes, spiders and scorpions, nasty creatures Laura Croft might encounter while raiding a tomb. Stemmer founded Maxygen of Redwood City, California, and later an antibody mimetic company Avidia, down the road in Mountain View, which was swallowed by-you guessed it-Amgen, in 2005.

Taking a cue from nanobodies, microsized antibodies isolated from camels and llamas (first published in Nature by a team of Brussels biologists in 1993), Stemmer's new company, Amunix, also in Mountain View, begins with a more noxious set of animals producing natural compounds that unexpectedly cause a very low immune response ${ }^{5}$. A phage display system generates proteins that the group further reduces in size to make them even less likely to be immunogenic. The final product, called a 'Versabody', is small, stable, and can be scaled to high titers by Escherichia coli. Delivery is where Amunix hopes to find its market. Monoclonal antibodies work on pathways outside of the cell, but nanobodies and Versabodies might be delivered inside the cell, making them ideal for home injection, or oral, pulmonary and transdermal delivery systems.

When it comes to next-generation $\mathrm{mAb}$ products, Stemmer thinks small. Regeneron's Yancopoulos thinks big: he sees value in humanizing the T-cell side of the immune system, such as optimizing a T-killer cell against a tumor. Then there's the practical approach. University of Illinois' Prabhakar sees a powerful tool for making vaccines to treat global disease. The tinkering with antibodies will continue, with unexpected and surprising results to follow.

Christopher Thomas Scott, San Francisco

1. Baker, M. Nat. Biotechnol. 23, 1065-1072 (2005).

2. Scott, C.T. Nat. Biotechnol. 23, 1037-1041 (2005).

3. Eisenstein, M. Nat Methods 1, 753-762 (2004).

4. King, J. Nat. Biotechnol. 24, 119 (2006).

5. Hamers-Casterman, C. et al. Nature 363, 446-448 (1993).

6. Coughlin, M. et al. Virology 361, 93-102 (2007).

7. Viau, M. et al. Mol. Immunol. 44, 2124-2134 (2007).

8. Saadeh, C.E. \& Lee, H.S. Ann. Pharmacother. 41, 606613 (2007)

9. Van Cutsem et al., J. Clin. Oncol. 25, 1658-1664 (2007).

10. Graven, U. et al. Br. J. Cancer 94, 1293-1299 (2006). 